\title{
Critical Investigation of Challenges in the Recognition of Customary Law in the Democratic South Africa
}

\author{
Sihawukele Ngubane \\ African Languages, Linguistics and Development Modules, School of Arts, University of KwaZulu-Natal, Durban, South Africa \\ Email address: \\ ngubanes@ukzn.ac.za \\ To cite this article: \\ Sihawukele Ngubane. Critical Investigation of Challenges in the Recognition of Customary Law in the Democratic South Africa. \\ International Journal of Law and Society. Vol. 2, No. 3, 2019, pp. 26-32. doi: 10.11648/j.ijls.20190203.11
}

Received: August 16, 2018; Accepted: March 22, 2019; Published: August 10, 2019

\begin{abstract}
This paper identifies indirect colonial rule as an impediment towards recognition of indigenous authority in South Africa. Indigenous Africans have observed customary law from time immemorial in the pre-colonial era to govern its own people with success before the establishment of British colonial policies. Indirect rule treated indigenous tribal chiefs as political intermediaries, which has caused imbalance of the application of law. This policy was used as a mechanism from which apartheid emerged during the twentieth Century and changed African political identity landscape to favour imperialistic ideology. We explore potential alignment in the application of customary law with common law in our courts to mark the democratic dispensation in the post-colonial era. This paper aims to explore the implications of different legal systems used in democratic post-apartheid South Africa and which are influenced by the apartheid legacy and the failure to recognise African values and principles. The influence of western values resulted in the omission of Ubuntu humanist philosophy from the Constitution of the Republic of South Africa, 1966 (Act 108 of 1996) (hereinafter referred to as "the Constitution").
\end{abstract}

Keywords: Customs, Customary Law, Indigenous Law, Tradition, Culture

\section{Introduction}

Various attempts were made from time immemorial to discard and discourage indigenous Africans to observe and obey customary law. The laws of colonial rulers were forced to Africans and attempts were further made to contaminate the African Culture and values. Defeated as Indigenous Africans were; stood up and fought for the observance of their customs [6]. That resistance necessitated the partial recognition of customary law and customs. Scholars such as Barrie (2000), Bennet and Pillay (2003) De Kock (1999), Himonga (2000), Kerr (2009), Ntlama (2012) and Praeg (2008) applied customary law in numerous cases as part of implementation of this law in spite of views against it $[2,3$, 11, 14, 26]. Van Niekerk (2005) declares that abolition of a rule that goes to the core of indigenous law will be a theoretical exercise and will deepen the divide between living and official indigenous law [27]. He further states that indigenous law and western law should be brought together in a relationship of equality through a process of harmonisation. The main argument of the paper is based on this premise and intend to demonstrate the fact that given a time in our democracy the two may be applied in our South African courts.

Customary law refers to the customs and usages traditionally observed by the indigenous African peoples of South Africa and which form part of the culture of those peoples - whether or not such customs and usages are codified. Culture is the way of life reflected in a person's behaviour, traditions and habits, which connect him or her to a particular group such as the Zulu nation. Customary Law and custom in South African is not written but in the then Natal and KwaZulu-Natal the main principles and some of the details of Zulu Law and custom were reduced to writing in the Code of Zulu Law which was completed in 1878 [6]. Other proclamations, for example, Cape Proclamation 142 of 1910, Cape Succession Act 18 of 1864 were promulgated in order to establish written law which had to be followed in adjudication of matters between Africans. The Black Administration Act 38 of 1927 (hereinafter referred to as the "Black Administration Act") was therefore an attempt to consolidate various laws and Chapter $1 \mathrm{~V}$ and $\mathrm{V}$ of Black Administration Act repealed all prior written customary laws and brought uniformity in the then four provinces regarding 
the constitution and jurisdiction of the special courts for hearing of suits and proceedings between indigenous Africans.

\section{Recognition of Customary Law in South Africa}

Chapter 12 (ss211 and 212) of the Constitution of South Africa, 1996, affords official recognition to customary law as well as to the institution, status and role of traditional leadership. Section 211 (3) mandates the courts to apply African Customary Law (ACL) where applicable. African Customary Law is also protected by the Bill of Rights under the right to freedom, belief and opinion. The Bill of Rights further provides any individual a right to language and culture as well as the collective right pertaining to cultural, religious, and linguistic communities. Customary law has been described as an established system of immemorial rules evolved from the way of life and natural context of which was a matter of common knowledge of the traditional leadership which was carried down from generation to generation.

The legitimacy of customary law as a legal system came about through the creation of the South African Constitution of 1996. The Constitution is the Supreme law of the Republic of South Africa and as it entrenches the legitimacy of customary, it therefore makes customary law to be unshaken and to be applied by our courts where it is appropriate but to the extent at which it does not negate any of the values in the Constitution. Section 39 (2) of the Constitution commands every court, tribunal or forum, when interpreting any legislation or when developing the customary law to promote the spirit, purport and objects of the Bill of Rights. Prior to colonisation, the applicable law in most African states was customary, having its sources in the practices, traditions, and customs of the people [24]. During the apartheid era, customary law was not recognised. Instead, the Dutch administrations relied on Roman-Dutch law in the years 1652 to 1672 . When the British Government took over the reins from the Dutch in 1806, customary law began to be recognised in a modest way. The English, like the Dutch, implemented their own law whilst recognising Roman-Dutch Law as the common law of the country (see Cape Articles of Capitulation 1806). Customary law was firstly codified as Native Law as the Africans were by then known as Natives." The resulting system emphasised the rights and authority of males and elders while it also emphasised the powerlessness and deference of women and juniors' [22]. The application of customary law was recognised if the customs and usages were not repugnant to morality or justice, and did not conflict, implicitly or explicitly, with any either public policy or written law [24]. In South Africa courts recognises the cultural, religious and linguistic communities as well as their normative orders described as customary law. Currie and De Waal (2013) states that: To prove membership of a cultural, religious or linguistic community some concrete tie of affirnity must be proved to exist between the individual and his community [9].

This presentation argues that conditions of the judicial application of customary law during the apartheid era led to the question of legitimacy or indirect rule in the new democratic society. The presentation will further explore the African customs and traditions; the challenges faced by traditional leadership in the dispensation of justice; and the infusion of customary law into the general framework of the law in judicial practice.

\section{Historical Account of Customary Law}

The introduction of the Black Administration Act 38 of 1927 meant that customary law was granted full recognition in both traditional and commissioner's courts [26]. The usage or application of customary law would be applied at the discretion of the commissioner. The recognition of customary law created a dual system with separate and inferior system of justice for Africans, and left the common law system of justice for all other South Africans [28]. The provisions of the Native Administration Act of 1927 included regulations on marriage, distinguishing between civil marriages and unions that did not constitute a legal marriage [25]. Women were recognised as minors and subjected to their husband's legal authority irrespective of age or marital status. Sibanda (2010) argues that the Act served as a means of entrenching a uniform system of indirect rule in South Africa whereby rational leaders became state agents in administering the affairs of those over whom they were appointed to rule [28]. This was evident through the establishment of the Traditional Leadership and Governance Framework Act No 41 of 2003. The objective of the Act was to recognise traditional communities; establish and recognise traditional councils and to provide a statutory framework within which traditional leadership will operate. The role of traditional leaders therefore, includes land administration; health and welfare, safety and security; the management of natural resources and disaster management. Provision for tribal levies from the Act (TLGFA) was enacted in Limpopo Limpopo Act No6 of 2005.

In 1988, the government introduced reform of the terms of recognition of customary law. Section 1 (1) of the Law of Evidence Amendment Act 45 of 1998 was passed to provide that:

Any court may take judicial notice of the law of a foreign state and of indigenous law in so far as such law can be ascertained readily and with sufficient certainty: Provided that indigenous law shall not be opposed to the principles of public policy or natural justice: Provided further that it shall not be lawful for any court to declare that the custom of lobola or other similar custom is repugnant to such principles.

Roman-Dutch common law has always been recognised as the general law of the country and sets the pace for customary law, but there is still a dire need to unify the legal system to reverse the injustices of the past and recognise the customs and traditions of the majority. 


\section{Human Rights and the Customary Law}

The Constitution entrenches human rights, democracy and coexistence for all South Africans irrespective of colour, race, class, belief or sex. In these provisions, exist conflicts between customary law and civil rights. The Constitution further gives everyone the right to practise his or her culture. Section 30 of the Constitution of South Africa 1996 provides the right to language and culture, while section 31 reaffirms the supremacy of the Bill of Rights in terms of legislation. Section 31 ensures that every person has the right to belong to and participate in cultural, religious or linguistic communities - although this provision is limited in that such rights may not conflict with any other provision articulated in the Bill of Rights. The application of customary law, as much as it is recognised by the Constitution, is not governed by any rules. This poses challenges, such as choosing which law to apply in certain cultural cases. The legacy of apartheid still prevails, and the influence of Native Administration Act of 1927 is still visible in our courts. The question that one may pose is whether the courts harmonised the legal system or whether the common law overrides customary law in the new democratic society.

This brief account of the legal history reveals that customary law has not received sufficient recognition to cater for African people. It was viewed as too backward to be included in the formal legal system and was limited to marriage, succession, and delict and land tenure. In some parts of the country such as the former Cape and the Transvaal, customary law had no official recognition. In Natal and Transkei, customary law was subject to the supervision of the higher courts. This inconsistency in the legal system is reminiscent of the apartheid era. The supremacy of common law in South Africa compromised traditional leaders, who lost the respect and support of their constituencies.

\section{Historical Account on Traditional Leadership in Kwa-Zulu}

The Nguni group in the largest in South Africa and it comprises of amaZulu, amaXhosa and amaSwazi. A process of political consolidation amongst the Zulu people began by the late eighteenth Century. King Shaka Zulu of Senzangakhona was the most renowned king of the Zulu nation. He transformed the small tribes into the largest and most powerful nation in South Africa. The dawn of apartheid in 1940 brought about changes that led to the South African government introduced the "homelands". The main aim was to form a tribal authority that will govern affairs of the Zulu people.

King Shaka has been viewed by historians as bloodthirsty, brutal and repressive - and yet he acted mainly by consensus of his executive. His leadership and governance structure were reinforced through the support of his subordinate leaders in their respective management and administrative levels: abanumzane (local ward administrators), izinduna (executive district managers), undunankulu (commander-inchief or prime minister) and ibandla (the king's council). Most South African historians refer to ward administrators as loyal chiefs appointed by the king, each administering his district in acknowledgement of the king and subordinate to the chief induna (undunankulu). Izinduna had the authority to adjudicate upon all matters, civil and criminal. On the other hand, ibandla (king's council) constituted elder clansmen of distinction and strong character who were capable of ruling and leading the nation. It included abantwana (aristocrats), izinduna and izilomo (the clan's elite). Izilomo formed part of the council although they had no special portfolio except to provide congenial company for the king. The king had legislative and judicial power, but in neither was he as autocratic as the powers exercised by the great Zulu kings have led us to suppose [18]. Custom was the main source of legislation although the king had no powers to make new laws without the consent of his councillors, who represented the people. The king is the personification of the law, and the representative of the tribal ancestors at the centre of ritual. An interesting observation by Krige (1936) is that the difference between African and European law is that Africans do not have the same distinction between crimes and civil offences as is found in Western society [18]. African judicial authorities are not concerned with crime. This limits their judicial powers.

\section{Democratic Dispensation in South Africa}

In 1994 South Africa entered a new constitutional dispensation based on democracy, equality, fundamental rights, the promotion of national unity and reconstruction. In this context, the position of traditional leaders had to be reevaluated. The role of traditional leaders was extensively dealt with in the Interim Constitution of 1993. An approach was provided by the Act No 41 of 2003 (TLGF) whereby a provision for houses of traditional leaders that was intended to regulate the functions and roles of traditional leaders. This move was preceded by the 1996 Constitution. Section 211 makes provision for the recognition of the institution, role and status of traditional leadership according to customary law subject to the Constitution. Traditional leaders function subject to applicable legislation and customs. The courts must apply customary law when it is applicable. The Constitution also states that national legislation must provide for the role of traditional leadership as an institution at local level on matters affecting local communities. Legislation may provide for the establishment of a national council of traditional leaders and provincial houses of traditional leaders. Provincial constitutions may also provide for the institution, role, authority and status of a traditional monarch. Provinces have legislative powers over traditional authorities and customary law. National legislation that applies 
uniformly in the country as a whole prevails over provincial legislation if any of the following conditions are met:

(1) The matter cannot be regulated effectively by legislation enacted by the provinces individually;

(2) The national legislation in order to ensure effectiveness and uniformity across the nation establishes norms and standards, frameworks or national policies;

(3) the national legislation is necessary for the maintenance of national security and economic unity, the protection of the common market, the promotion of economic activities across provincial boundaries and equal opportunity or equal access to government services and the protection of the environment;

(4) the national legislation is aimed at preventing unreasonable action by a province that is prejudicial to the economic, health or security interests of another province or the country as a whole or impedes the implementation of national economic policy - s 146 (3). Six S 104 read with schedule 4.

A Traditional courts as an institution also received constitutional recognition in section 166, although indirectly, as "any other courts established or recognised by an Act of Parliament, which may include any court of a status similar to either the High Courts or the Magistrates' Courts". Traditional courts were recognised in the Black Administration Act as well as by former homelands' legislation. The Law Commission did an extensive study on the functioning of these courts and is in the process of formulating proposals in this regard. The traditional courts are continuing to function and exercise jurisdiction in terms of sections 12 and 20 of the Black Administration Act 38 of 1927 until the new legislation is passed by Parliament and the effective date thereon is proclaimed by the State President according to The Repeal of Certain Laws Amendment Act 20 of 2012 published on 19 December 2012 through Government Gazette No. 36021 Volume 570.

A Kgosi (or traditional leader) is a kgosi ke kgosi ka batho ("a leader which is a leader through his people"), the father of his people and a binding and spiritual factor that serves as symbol of the unity of the group. He or she is seen by most people as the embodiment of law and order, the upholder of values and as provider for the needs of the community and, in some instances, even as an institution created by God. To say that the institution of traditional leadership is not democratic may be true from a Western perspective of what is to be understood under democracy, but such a view ignores the concepts of African democracy and ubuntu.

Democracy was experienced as a participatory democratic style in the consensus-seeking traditional authorities; a command-style in some participatory traditional authorities. In several studies, it has been indicated that traditional leaders have a role to play as an institution at local level. Their role at provincial and national level in the National House of Traditional Leaders and the Provincial Houses of Traditional Leaders has not yet been clearly defined. The National and Provincial Houses of Traditional Leaders experience various problems that hamper their functioning.

\section{Discussion}

According to the Law Commission, all courts in South Africa are competent to apply customary law. Under section 12(1) of the Black Administration Act, however, courts of traditional authorities only have jurisdiction to hear and determine civil claims arising out of African law and custom brought before them by Africans within their areas of jurisdiction. This indicates that traditional courts are not competent to apply common law. On the other hand, according to section 20(1) (a) of the same Act, traditional leaders may try certain offences at either common or customary law; provided the accused was African Black or the victim was African. This promotes segregation in the legal system that dictates that Western standards are superior to African culture. While the provision of Black Administration Act was with exception of section 12 and 20, replaced the application of customary law is still compromised by our legal system. Criminal cases held that violations of the criminal law could not be justified on the basis that the offence was based on customary practice. Traditional leadership as provided by Act No 41 of 2003, are responsible for dispute resolution and the establishment of the Commission on Traditional Leadership Disputes and Claims and to provide for a code of conduct and other matters.

Cases of marriage contracts create uncertainties and conflicts in terms of lobolo customs. The feeling of most people is that this custom should be regulated for its validity. Another controversy concerns the infidelity of married couples; according to customary law, lobolo is not returned. If the husband is involved, it is not taken seriously and does not amount to a divorce. In the common law, on the other hand, adultery by either spouse may lead to a divorce. The word " $u k w e n d a$ " (to die) implies that when a woman chooses to be married, there is no way that she can return home. The concept suggest that she will die with the in-laws. The kist suggests a coffin. The contract of marriage is misunderstood by Western values, which advocate that it can be terminated any time. It is a Christian belief that when two people are joined they will only be separated by death - a notion of "till death do us part". Umgcagco (wedding) has no divorce.

The other issue is the contract of marriage, in the customary law the contract or union may continue until two families reach a decision to terminate the contract. Mourning takes twelve months before the spouse decides whether to stay within the family or move on. There is a ritual where slaughtering of a cow takes place. On the day when meat is served, the bride leaves home early in the morning, which is a sign that she is moving on. In an African set-up, the aim of marriage is to bring two families together, rather than two individuals. Under the common law, death automatically terminates marriages. If the wife choses to stay, ukungena custom is applied. Ukungena implies that a brother may take responsibilities of his late brother in taking care of his sisterin-law as a guardian.

Issues of guardianship in the African concept is not 
regulated - most people accept that the grandmother or grandfather may take over without following any legislation, such as consultation with Social Workers and Home Affairs. The court order is not necessary when family members has to adopt a child, "Ingane kaGogo" (Granny's child) is no way disputed in the African context. The concept of Ubuntu operates in good faith and should be adopted to infuse African social systems into common law. Curriculum reform by scholars and researchers should be encouraged to develop African values. Common law will continue to exist in South Africa only when and if it fuses itself with customary law and becomes an integral part of a new South African Law, as it was the case with Roman-Dutch Law and English law (statutory law) which represented values of the minority people of South Africa in the apartheid era. Through this infusion of the legal system with Ubuntu, human dignity will be restored. One argues that the humanistic value of Ubuntu should be adopted to infuse African equity into common law. Different people have translated Ubuntu differently; it has been commercialised and politicized in the corners of the public. I understand the concept to mean "humanity", "personhood" or "humanness. The essence of Ubuntu is sharing, caring, and ethical behaviour, which has cultural underpinnings.

According to Bennet (2011) the word Ubuntu provided a gateway for African ideas and values to infuse South African law [4]. Truth and Reconciliation Commission was established on the premise of Ubuntu that was intended to promote national unity and Reconciliation. Ubuntu is a mean to a personal and national sense of justice. Isikweletu (credit) for instance, is not forgotten in the African culture. If you owed a cow to someone that would paid over many years regardless of existence of such individual to children or grandchildren. Traditional to pay all lobola at once was an insult hence a saying that, "Umfazi akaqedwa" (a bride is never paid in full). In some instances, the last cow would be paid after few children are born or children will pay the debt on behalf of the parent. As Mokgoro (1966/67) argues that in the case of Mthembu v Letsela and Another, a rule in African Customary Law, which excluded women from intestate succession, is inconsistent with the provisions of the equality clause [20]. This rule was supported by the courts on the basis that it was not inconsistent with fundamental rights as stipulated in the Constitution of South Africa 1996. From this view, it is evident that under customary law, offenses are treated as private wrongdoing rather than crimes. In a number of offenses against the society or the state agreement between the two parties is negotiated. The wrongs of the leaving against the non-living is negotiated through ritual or ancestor venerations. Once you are guilty, the charge is given but there sentencing. "Eyamadoda ayipheli" (the war between two men does not end) performed by Zola 7. The infusion of Customary Law and Common law should take into cognisance the African way of conflict resolutions and become integrated as a single South African Law.

Makgoro (1998) held that;

Metaphorically, Ubuntu expresses itself in umuntu ngumuntu ngabantu, (you are who you are through others) describing the significance of group solidarity on survival issues so central to the survival of communities. While it envelops the key values of group solidarity, compassion, respect, human dignity, conformity to basic norms and collective unity, in its fundamental sense it denotes humanity and morality [21]. Its spirit emphasises respect for human dignity, marking a shift from confrontation to conciliation.

A common view of the concept of "Ubuntu" is that it is lived and practiced by African societies and is considered a world-view of Africans in general. Mokgoro further describe "ubuntu' as a philosophy of life, which is its most fundamental sense represents personhood, humanity, humaneness and morality; a metaphor that describes group solidarity where such group solidarity is central to the survival of communities with a scarcity of resources. Ubuntu therefore, is a humanistic orientation towards other people.

Kunene (1996) states that:

"Ubuntu is the very quality that guarantees not only a separation between men, women and the beast, but the very fluctuating gradations that determine the relative quality of that essence." [17]

Langa cited by [20] adds to the definition as follows:

"It is a culture, which places some emphasis on communality and on the interdependence of the members of a community. It recognises a person's status as a human being, entitled to unconditional respect, dignity, value and acceptance from the members of the community.

It is true to the human rights requirement to apply justice in respect and honouring ones language. Infusing Ubuntu to our common law will be a practice of the concept and in a humanistic many "the African way".

There is still minimal application of African customary law in South Africa. Debates and dialogue are required to bring about a solution on how it should be applied alongside the common law. Let me conclude by a quotation from the judge president of Cape Town, Justice Hlophe:

If one accepts that African Customary Law is recognised in terms of the constitution and relevant legislation to give effect to the constitution, such as the recognition of Customary Marriages Act No. 120 of 1998 referred to above, there is no reason, in my view, why the courts should be slow at developing African Customary Law. The proper approach is to accept that the Constitution is the supreme law of the Republic. Thus, any custom, which is inconsistent with the Constitution, cannot withstand constitutional scrutiny. With this view, it is therefore, necessary that the Bill of Rights and African Customary Law should be reconciled and applied in all our courts in South Africa.

According to the review of Ubuntu and customary law in South Africa Himonga, Taylor and Pope (2013) attest that although Ubuntu can be applied to virtually any area of law and hence its development has not always followed a clear thematic path, they think that there is scholarly value in emphasising a particular thematic strand in the judicial application of the concept of ubuntu, namely its link to restorative justice [12]. There a certain areas of law, such as 
criminal law, defamation law and eviction cases that may be looked at applying the theme of restorative justice. They further argue that Ubuntu is not a technocratic concept and yet it calls for wisdom and open-mindedness. This view explains the significance of Ubuntu in enhancing human dignity, conformity to basic norms and collective unity and moral regeneration. Himonga (2013) further suggest that the lack of precise meaning of Ubungu is consistent with its nature as a value of the South African Constitution and can only be conceived of in abstract terms [12]. It is therefore necessary to associate Ubuntu with the idea of communal and collective behaviour, interdependence, dignity and solidarity amongst African people.

\section{Conclusion}

The paper has attempted to pave a way for a possible infusion and application of customary law into common law; reviving and restoring of African values in our judicial system that will embrace everyone irrespective of colour or creed. The infusion of customary law will resolve misunderstanding caused by African traditions and culture to cater for a conducive environment for reconciliation and nation building of South Africa. African values are in consonance with the values of the Constitution of South Africa 1996 and those of the Bill of Rights. Perhaps most importantly, it will redeem the trust and confidence of the majority of our people in the justice system. After all, the legitimacy of the judiciary, in particular, is dependent in no small measure, upon the people's confidence in the law as it is applied and understood in twentyfour years into Democracy, we surely cannot risk the justice system losing its legitimacy. The paper has argued that Ubuntu can play a critical role in the justice system of South Africa as a legal concept once implemented as the Constitution of South Africa recognises it. Makeri in Ntlama (2012) points out that... because in the past it was disliked, ridiculed and discouraged by apartheid rulers. [26] It did not form part of their culture as it was alien to them and was systematically eroded and replaced with imported laws". It is therefore evident that the notion may be fixed in the quest of nation building.

\section{References}

[1] Act 8 of 1984; KwaZulu Amakhosi and Iziphakanyiswa Act 9 of 1999; cf also Bekker "Outline of Constitution, jurisdiction and procedure of Traditional Authority Courts".

[2] Barrie, GN 2000. Ubuntu ungamtu ngabaye abantu: The Recognition of Minority Rights in the South African Constitution. SALJ 271.

[3] Bennet, TW and Pillay A 2003. The Natal and KwaZuluCodes: The Case for Repeal. SAJHR 217 Volume 19.

[4] Bennet, TW, 2011. Ubuntu: An African Equity South African Journal on Human Rights Volume 14 (4).

[5] Bennett T. W. 1985. Contemporary African Customary Law in Southern Africa 26.
[6] Bekker J. C. 1989. Seymour's Customary Law in Southern Africa: https://www.amazon.com.

[7] The Black Administration Act, 1927. http://www.justice.gov.za.

[8] The Cape Articles of Capitulation, 1806. http://www.nelsonmandela.org.

[9] Currie I. and De Waal J. 2013. The Bill of Rights handbook. $6^{\text {th }}$ edition. Juta. Cape Town.

[10] Constitution of the Republic of South Africa 1996.

[11] De Kock, PD \& Labuschagne, LMT 1999. Ubuntu as a Conceptual Directive in Realising a Culture of Effective Human Rights. 62 THRHR 114.

[12] Himonga C, Taylor M and Pope A 2013 Reflections on judicial views of Ubuntu. Potchefstroom Electronic Law $\begin{array}{llll}\text { Journal. } & \text { Volume } & 16 & \text { No. }\end{array}$ http://dx.doi.org/10.4314/pelj.v16i5.8

[13] Kerr, AJ. 1994. Customary Law, Fundamental Rights, and the Constitution 111 SALJ (720-735).

[14] Kerr, AJ. 2009. The Constitution and Customary Law, SALJ $126(39-50)$.

[15] Koers. 1999. Traditional Authorities Research Group (297298).

[16] Konrad Adenauer-Stiftung 1997. Traditional leadership in Southern Africa (80-81).

[17] Kunene M. 1996, The Essence of being Human: An African Perspective" Inaugural lecture 16 August, Durban.

[18] Krige E J. 1936. The Social System of the Zulus. Shuter \& Shooter. Pietermaritzburg.

[19] Makeri, SH. 2007. Jurisdictional issues in the application of customary law in Nigeria. (Unpublished paper presented at the Conference The Judiciary and the Challenges of Nation Building 5-9 September. Kaduna State.

[20] Makgoro JY. 1996/97 The Customary Law question in the South African Constitution.

[21] Makgoro JY. 1998 Ubuntu and the law in South Africa https://www.ajol.info.

[22] McClendon, T. 1995. "Tradition and Domestic Struggle in the Courtroom: Customary Law and the Control of Women in Segregation-Era Natal," The International Journal of African Historical Studies. Vol. 28, No. 3 pp. 527-561.

[23] Mohomed I. 1999. Project 90: The harmonisation of the common law and the indigenous law report on conflicts of law. South African Law Commission. http://www. Law.wits.ac.za/salc/salc.html.

[24] Ndulo M. 2011. "African Customary Law, Customs, and Women's Rights". Indiana Journal of Global Legal Studies. 18 (1).

[25] Nhlapho, T. 2005. "The Judicial Function of Traditional Leaders: A Contribution to Restorartive Justice?" Unpublished paper presented at the Conference of the Association of Law Reform Agencies of Eastern and Southern Africa. Vineyard Hotel. Cape Town. 
[26] Ntlama, N. 2012. The Application of Section 8 (3) of the Constitution in the Development of Customary Law Values in South Africa's New Constittutional Dispensation. SALJ Vol 15 (1) PER 24.

[27] Rautenbach C. 2008: South African Common and Customary law of Intestate Succession: A question of Harmonisation, Integration or Abolition. Electronic Journal of Comparative Law Vol. 12.1 (May 2008), http://www.ejcl.org.

[28] Sibanda, S. 2010. "When is the Past not the Past? Reflections on Customary Law under south Africa's Constitutional Dispensation" Unpublished paper presented at the Conference Custom, Law and Tradition: Alternative Legal systems and Their Impact on Human Rights American University Washington school of Law.

[29] Unpublished speech delivered at Workshop Customary Courts SA Law Commission 9 September 1999. South African Law Commission The harmonisation of the common law and indigenous law: Traditional courts and the judicial function of Traditional leaders Project 90 Discussion Paper 82. (Pretoria 1999).

[30] Van Niekerk GJ, 2005. Succession, living indigenous law and Ubuntu in the Constitutional Court. Volume 26 (3) p. 474 487. 